\title{
PENGARUH LOCUS OF CONTROL TERHADAP KINERJA AUDITOR PADA INSPEKTORAT DAERAH KABUPATEN KONAWE
}

\author{
Oleh \\ Fitriaman ${ }^{1}$, Husin ${ }^{2}$, Sulfiani Pagala ${ }^{3}$ \\ Jurusan Akuntansi Fakultas Ekonomi dan Bisnis Universitas Halu Oleo Kendari \\ Sulawesi Tenggara
}

\begin{abstract}
ABSTRAK
Penelitian ini bertujuan untuk mengetahui dan menganalisis pengaruh penggunaan Sistem Teknologi Informasi (Aplikasi SAS) terhadap kualitas laporan keuangan pada Balai latihan Kerja Kendari. Jenis penelitian yang digunakan dalam penelitian ini adalah penelitian kausalitas dengan pendekatan kuantitatif. Teknik sampel yang digunakan dalam penelitian ini adalah sensus sampling, dimana sampel dalam penelitian ini merupakan Tim Penyusun Laporan Keuangan Anggaran Pendapatan dan Belanja Negara (APBN) pada Satuan Kerja Balai Latihan Kerja Kendari sebanyak 40 orang. Instrumen penelitian menggunakan kuesioner, sedangkan alat analisis yang digunakan adalah analisis regresi linear sederhana menggunakan skala interval.

Hasil penelitian ini menunjukkan bahwa Sistem Teknologi Informasi berpengaruh signifikan terhadap Kualitas Laporan Keuangan pada Balai Latihan Kerja (BLK) Kendari. Balai Latihan Kerja (BLK) Kendari telah mampu dalam menerapkan serta memanfaatkan fungsi dari sistem teknologi informasi berupa Sistem Aplikasi Satker (SAS) dalam segala mekanisme pengelolaan laporan keuangan secara tepat dan maksimal, sehingga pemanfaatan sistem teknologi informasi ini akan berdampak pada kemudahan dalam melaksanakan tugas utamanya berkaitan dengan pengolahan laporan keuangan secara lebih tepat, cepat, dan berkualitas dalam rangka memenuhi segala pertanggungjawaban keuangan yang terjadi selama Balai Latihan Kerja (BLK) Kendari memenuhi tujuan serta visi dan misi organisasinya.
\end{abstract}

Kata Kunci : sistem teknologi informasi, kualitas, laporan keuangan.

\begin{abstract}
This research aim to determine and analyze the influence of the Locus of Control to the Auditor Performance at the Regional Inspectorate of Konawe Regency. This type of research used in this research is qualitative and quantitative. The sample technique used in this research is saturated sampling, where the sample in this research were 23 auditors of the Konawe District Inspectorate. The research instrument used questionnaire, while the analysis tool used was simple linear regression analysis. The results of this research indicate that the regression coefficient is positive, so it can be said that the locus of control on auditor performance has a signifficant influence.
\end{abstract}

Keywords $\quad$ : Locus of Control, Auditor Performance

\section{PENDAHULUAN}

Tuntutan pelaksanaan akuntabilitas sektor publik terhadap terwujudnya tata kelola pemerintahan yang baik (good governance) di Indonesia semakin meningkat. Good Governance pada dasarnya adalah suatu konsep yang mengacu kepada proses pencapaian keputusan dan pelaksanaannya yang dapat diprrtanggungawabkan secara bersama. Sebagai suatu konsensus yang dicapai oleh pemerintah, warga negara, dan sektor swasta bagi penyelenggaraan pemerintahan di suatu negara. 
Tuntutan ini memang wajar, karena beberapa penelitian menunjukkan bahwa terjadinya krisis ekonomi di Indonesia ternyata disebabkan oleh buruknya pengelolaan pemerintahan (Bad governance) dan buruknya birokrasi. Dalam beberapa tahun terakhir, banyak terjadi permasalahan hukum terutama yang berkaitan dengan korupsi, kolusi, dan nepotisme (KKN) dengan segala praktiknya seperti penyalahgunaan wewenang, penyuapan, pemberian uang pelicin, pungutan liar, pemberian imbalan atas dasar kolusi dan nepotisme.

Pengawasan merupakan salah satu fungsi manajemen yang tidak dapat dipisahkan dengan fungsi manajemen lainnya yaitu perencanaan, pengorganisasian dan pelaksanaan. Efektifitas pelaksanaan pengawasan sangat penting dalam menjalankan pembangunan dan pemerintahan. Dalam sistem pengendalian internal pemerintah, pelaksanaan pengendalian internal tersebut diberikan wewenang kepada Aparat Pengawasan Fungsional Pemerintah (APFP) yang dilaksanakan salah satunya oleh Badan Pengawas Daerah/Inspektorat. Inspektorat daerah mempunyai tugas menyelenggarakan kegiatan pengawasan umum pemerintah daerah dan tugas lain yang diberikan kepala daerah, sehingga dalam tugasnya inspektorat sama dengan auditor internal.

Berita tentang adanya sejumlah desa yang diduga "fiktif" di Kabupaten Konawe 2019 lalu tentu merupakan kabar yang cukup menyita perhatian masyarakat dan hingga saat ini yang telah terkonfirmasi bahwasanya bukan merupakan desa "fiktif" tersebut baru sebagian kecil. Sedangkan untuk sebagian lainnya masih dalam tahap verifikasi ulang. Mencuatnya kasus ini ke publik tentu saja membuat Pemerintah Daerah dan Inspektorat tak luput dari perbincangan. Temuan Inspektorat Provinsi Sulawesi Tenggara Nomor 700/49 perihal hasil klarifikasi monitoring penyaluran Dana Desa Kabupaten Konawe Tahun Anggaran 2015-2018 yang dimana kesimpulannya adalah Dana Desa untuk Desa Ulu Meraka, Desa Uepai dan Desa Morehe pada periode tahun 2015-2018 sebesar Rp. 5.084.543.000 telah di transfer dari Rekening Kas Umum Negara ke Rekening Kas Daerah Kabupaten Konawe (Sumber: desapedia.id). Jika tidak ada Pengawasan yang ketat, Indonesia Corruption Watch (ICW) memprediksi hal tersebut akan menjadi "Gaya Korupsi Baru" artinya kedepan bisa jadi menjadi tren, menjadi anggaran yang dapat dijadikan sebagai ruang korupsi yang baru, karena bicara soal korupsi desa itu bicara soal anggaran yang seharusnya didistribusikan ke desa.

Inspektorat sebagai salah satu pelaksana tugas pengendalian internal pemerintah, mempunyai kewajiban melakukan pengawasan terhadap pelaksanaan keuangan sesuai dengan peraturan perundang-undangan yang berlaku. Auditor dituntut harus memiliki keahlian dan pelatihan yang cukup. Auditor harus memiliki pengetahuan mengenai metode dan teknik audit serta segala hal yang menyangkut pemerintahan. Keahlian auditor dapat diperoleh melalui pendidikan dan pelatihan yang berkelanjutan serta pengalaman yang memadai dalam melaksanakan audit. Oleh karena itu seorang auditor harus mampu menerapkan kemampuan, pengetahuan dan pengalaman.Dalam menjalankan fungsi pemeriksaannya, maka Inspektorat perlu didukung oleh Kinerja Auditornya.

Kinerja adalah gambaran mengenai tingkat pencapaian pelaksanaan suatu kegiatan/program/kebijakan dalam mewujudkan sasaran, tujuan, misi dan visi organisasi yang tertuang dalam perumusan skema strategis (strcategic planning) suatu organisasi (Indra Bastian, 2001). Kinerja Auditor dipengaruhi oleh faktor-faktor teknis dan faktorfaktor non teknis. Faktor-faktor teknis berkaitan dengan program dan prosedur audit. Sedangkan faktor-faktor non teknis meliputi masalah-masalah yang berkaitan dengan sikap, mental, locus of control, pengalaman, dan kemampuan yang dirasakan (Engko dan Gudono, 2007). 
Faktor non teknis yang ingin peneliti perdalam adalah tentang Locus of control. Locus of control adalah tingkatan seseorang dalam menerima tanggungjawab personal terhadap apa yang terjadi pada diri mereka.

Berdasarkan fenomena yang dipaparkan oleh peneliti, guna menghindari adanya praktik "korupsi gaya baru " dalam lingkungan pemerintahan daerah, mengingat Inspektorat daerah berada dibawah dan bertanggungawab kepada Kepala Daerah, oleh karenanya, maka perlu adanya variabel yang dapat mempengaruhi dan mengendalikan perilaku-perilaku auditor seperti itu, dan kepribadian atau variabel tersebut adalah Locus $f$ Control. Hal tersebut diatas mendorong peneliti untuk melakukan penelitian mengenai Locus of control, terhadap Kinerja Auditor dengan mengambil objek penelitian yakni di Inspektorat Daerah Kabupaten Konawe. Dengan judul penelitian "Pengaruh Locus of Control Terhadap Kinerja Auditor Pada Inspektorat.

\section{Akuntansi Keperilakuan}

\section{TINJAUAN PUSTAKA}

Sebagai bagian dari ilmu keperilakuan (behavior science), teori-teori akuntansi keperilakuan dikembangkan dari riset empiris atas perilaku manusiadalam organisasi. Teori dasar dalam akuntansi keperilakuan adalah Teori Psikologi.

Teori psikologi yang mempunyai pandangan mendalam tentang perilaku manusia adalah Theory of Reason Action (Trabelsia, Labelle, dan Dumontier, 2008) yang kemudian dikembangkan menjadi Theory of Planned Behaviour (TPB) (Ajzen, 1991, 2005; Ajzen dan Madden, 1986), menjelaskan bahwa perilaku individu yang berpeluang terjadi karena dipicu oleh beberapa faktor yaitu internal dan eksternal. Faktor internal yang mempengaruhi perilaku manusia adalah pribadi dari manusia itu sendiri, dan faktor eksternal adalah kondisi sosial dan informasi.

\section{Audit}

Mulyadi (2002) menyebutkan pengertian Audit sebagai Suatu proses sistematik untuk memperoleh dan mengevaluasi bukti secara objektif mengenai pernyataanpernyataan tentang kegiatan dan kejadian ekonomi dengan tujuan untuk menetapkan tingkat kesesuaian antara pernyataan-pernyataan tersebut dengan kriteria yang telah ditetapkan, serta penyampaian hasil-hasilnya kepada pemakai yang berkepentingan.

\section{Locus of Control}

Konsep locus of control pertama kali dikemukakan oleh Rotter berdasarkan pendekatan social learning theory. Menurut Pevin dalam Ayudiati (2010) konsep locus of control adalah bagian dari social learning theory yang menyangkut kepribadian dan mewakili harapan umum mengenai masalah faktor-faktor yang menentukan keberhasilan, pujian, dan hukuman terhadap kehidupan seseorang. Locus of control adalah cara pandang seseorang terhadap peristiwa apakah dia merasa dapat atau tidak dapat mengendalikan peristiwa yang terjadi padanya (Rotter, 1996 dalam Ayudiati, 2010). Brownell (1981) menulis tentang pendapat Rotter dalam papernya yang mendefinisikan locus of control sebagai tingkatan dimana seseorang menerima tanggung jawab personal terhadapa apa yangvterjadi pada diri mereka.

\section{Internal locus of control}

Internal locus of control adalah cara pandang bahwa segala hasil yang didapat baik atau buruk adalah karena tindakan kapasitas dan faktor-faktor dalam diri mereka sendiri. Internal locus of control yang dikemukakan Lee (1990) dalam Ayudiati (2010) adalah keyakinan seseorang bahwa di dalam dirinya tersimpan potensi besar untuk menentukan nasib sendiri, tidak peduli apakah lingkungannya akan mendukung atau tidak mendukung. Individu seperti ini memiliki etos kerja yang tinggi, tabah menghadapi segala macam 
kesulitan baik dalam kehidupannya maupun dalam pekerjaannya. Adanya perasaan khawatir dalam diri individu relatif kecil dibanding dengan semangat serta keberaniannya untuk menentang dirinya sendirisehhingga orang-orang seperti ini tidak pernah ingin melarikan diri dari tiap-tiap masalah dalam bekerja.

\section{External locus of control}

External locus of controlyaitu cara pandang dimana segala hasil yang didapat baik atau buruk berada di luar kontrol diri merekayang disebabkan oleh faktor luar seperti keberuntungan, kesempatan, dan takdir. Individu yang termasuk dalam kategori ini meletakkan tanggung jawab di luar kendalinya. External locus of control yang dikemukakan oleh Lee (1990) adalah individu yang external locus of controlnya cukup tinggi akan mudah pasrah dan menyerah jika sewaktu-waktu terjadi persoalan yang sulit. Individu semacam ini akan menganggap permasalahan yang datang menjadi sebuah ancaman bagi dirinya. Apabila seseorang mengalami kegagalan atau tidak dapat menyelesaikan suatu permasalahan, maka individu tersebut akan menganggap suatu kegagalan sebagai nasib dan membuatnya ingin lari dari persoalan.

Menurut Crider (1983) perbedaan karakteristik antara internal dan external locus of control adalah sebagai berikut:

1) Internal Locus of Control

a) Suka bekerja keras

b) Memiliki inisiatif yang tinggi

c) Selalu berusaha untuk menemukan pemecahan masalah

d) Selalu mencoba untuk berfikir seefektif mungkin

e) Selalu mempunyai persepsi bahwa usaha harus dilakukan jika ingin berhasil.

2) External Locus of Control

a) Kurang memiliki inisiatif

b) Mudah menyerah, kurang suka berusaha karena mereka percaya bahwa faktor luarlah yang mengontro006C

c) Kurang mencari informasi

d) Mempunyai harapan bahwa ada sedikit korelasi antara usaha dan kesuksesan

e) Mulai dipengaruhi dan bergantung pada petunjuk orang lain.

Luthans (2006) dalam buku Perilaku Organisasi mengemukakan bahwa karyawan yang memiliki kontrol internal merasa bahwa secara personal mereka dapat mempengaruhi hasil melalui kemampuan, keahlian, atau usaha mereka sendiri. Karyawan yang memiliki kontrol eksternal merasa bahwa kekuatan eksternal seperti kebeeruntungan dan kesulitan tugas mengontrol hasil mereka.

\section{Kinerja}

Menurut Mangkunegara dalam Wikipedia Bahasa Indonesia, menjelaskan bahwa istilah kinerja berasal dari kata job performance (prestasi kerja atau prestasi sesungguhnya yang dicapai seseorang) yaitu hasil kerja secara kualitas dan kuantitas yang dicapai oleh seorang pegawai dalam melaksanakan tugasnya sesuai dengan tanggung jawab yang diberikan organisasi. Kinerja individu adalah hasil kerja karyawan baik dari segi kualitas maupun kuantitas berdasarkan standar kerja yang telah ditentukan, sedangkan kinerja organisasi adalah gabungan dari kinerja individu dengan kinerja kelompok.

Menurut Wirawan (2009) untuk mengukur kinerja dapat menggunakan indikator-indikator sebagai berikut:

a) Kuantitas hasil kerja yaitu kemampuan karyawan dalam menyelesaikan sejumlah tugas hariannya.

b) Kualitas hasil kerja yaitu kemampuan karyawan menunjukkan kualitas hasil kerja ditinjau dari segi ketelitian dan kerapian. 
c) Ketepatan Penyelesaian tugas merupakan pengelolaan waktu dalam bekerja dan juga ketepatan karyawan dalam menyelesaikan

\section{Auditor Internal}

Standar Profesional Audit Internal (2004:27) : “Auditor Internal adalah seseorang yang memiliki keahlian dan profesional untuk memberikan nilai tambah bagi organisasi dengan cara meningkatkan peluang untuk mencapai tujuan organisasi, mengidentifikasi perbaikan operasi, dan atau mengurangi melalui jasa assurance dan jasa konsultasi "

Ada banyak lembaga audit internal yang bersifat permanen dengan tugas membanttu manajemen di bidang pengawasan dalam pengelolaan keuangan, antara lain (STAN, 2007):

a.) Badan Pengawasan Keuangan dan Pembangunan (BPKP), yaitu lembaga audit internal pemerintah pusat, dibentuk dengan Keputusan Presiden, berada di bawah dan bertanggung jawab kepada Presiden.

b.) Inspektorat Jenderal Kementerian/Unit Pengawasan Lembaga Pemerintah Non Departemen (LPND), merupakan auditorinternal di lingkungan masing-masing Kementerian/LPND.

c.) Inspektorat Provinsi, Inspektorat Kabupaten/Kota sebagai auditorinternal di lingkungan Pemerintahan Daerah Provinsi, Kabupaten/Kota.

d.) Auditor internal pada Badan-badan Usaha Milik Negara (BUMN)dan swasta yang disebut dengan berbagai istilah, seperti SatuanPemeriksa Intern (SPI), Kantor Audit Internal (KAI), Satuan Kerja Audit Internal (SKAI).

Jabatan fungsional dalam auditor internal pemerintah adalah :

a) Auditor trampil, teridri dari:
1) Auditor pelaksana
2) Auditor pelaksana lanjutan
3) Auditor penyelia

b) Auditor ahli, terdiri dari:

1) Auditor pertama

2) Auditor muda

3) Auditor madya

4) Auditor utama

\section{Paradigma Penelitian}

Pada penelitian ini akan diteliti besaran pengaruh Locus Of Control (X) terhadap Kinerja Auditor. Dalam hal ini Locus of Control sebagai variabel Bebas dan Kinerja Auditor sebagai variabel terikat.

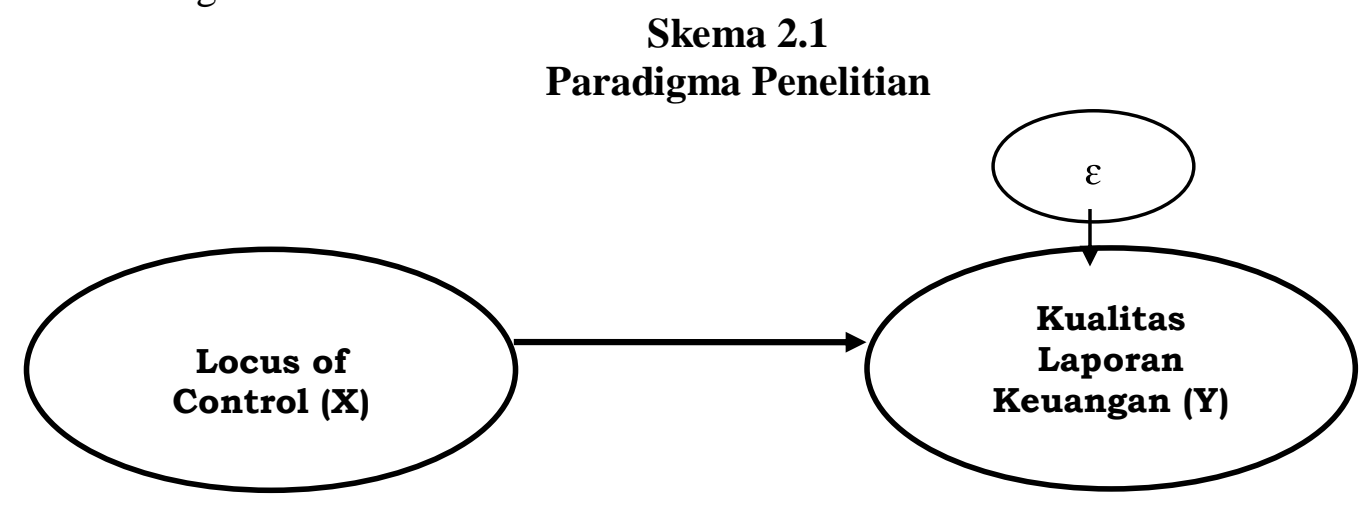

\section{Perumusan Hipotesis}

Locus of control merupakan salah satu variabel kepribadian (personaility), yang didefinisikan sebagai keyakinan individu terhadap mampu tidaknya mengontrol nasib (destiny) sendiri. 
Jurnal Akuntansi dan Keuangan (JAK)

Volume 6, No. 1 Februari Tahun 2021

Page: $203-216$

http://ojs.uho.ac.id/index.php/jak-uho/issue/archive

e-ISSN: 2088-4656

Penelitian Samudra Perwira Budiman (2010) "Pengaruh Struktur Audit, Locus of Control dan Komitmen Organisasi terhadap kinerja Auditor Pemerintah (Studi Empiris Pada Auditor Pemerintah di Inspektorat Kab. Agam, Kota Padang dan Kota Padang Panjang). Hasil dari penelitian ini mengindikasikan bahwa LOC memiliki pengaruh terhadap kinerja Auditor.

Berdasarkan uraian di atas, maka dapat dirumuskan hipotesis utamanya sebagai berikut:

$\mathrm{H}_{0} \quad$ : Tidak ada pengaruh yang signifikan antara locus of control terhadap Kinerja Auditor Pada Inspektorat Daerah Kabupaten Konawe

$\mathrm{H}_{1} \quad$ : Terdapat pengaruh yang signifikan antara locus of control terhadap Kinerja Auditor Inspektorat Kab. Konawe.

\section{METODE PENELITIAN}

Objek dalam penelitian ini adalah Locus of Control dan Kinerja Auditor. Penelitian ini di lakukan di Inspektorat Kabupaten Konawe yang beralamat di Jl.Inolobunggadue II No. 332 Telp/Fax (0408) 21393 Unaaha.

Populasi dalam penelitian ini adalah Auditor Inspektorat Daerah Kabupaten Konawe yang berjumlah 26 orang. Sedangkan teknik sampel yang digunakan dalam penelitian ini adalah sampling jenuh yaitu teknik penentuan sampel bila semua anggota populasi digunakan sebagai sampel. Adapun jumlah sampel sama dengan jumlah populasi yang merupakan Tim Penyusun Laporan Keuangan Anggaran Pendapatan dan Belanja Negara (APBN) pada Satuan Kerja Balai Latihan Kerja Kendari sebanyak 26 orang dengan rincian sebagai berikut.

Tabel 3.1

Daftar Sampel Penelitian di Inspektorat Kabupaten Konawe

\begin{tabular}{|l|l|}
\hline \multicolumn{1}{|c|}{ Sub Unit } & \multicolumn{1}{c|}{$\begin{array}{c}\text { Jumlah } \\
\text { Auditor }\end{array}$} \\
\hline Inspektur Pembantu Wil.I & 1 \\
\hline Inspektur Pembantu Wil.II & 1 \\
\hline Inspektur Pembantu Wil.III & 1 \\
\hline Inspektur Pembantu Wil. IV & 1 \\
\hline Auditor Irban Wil. I & 3 \\
\hline Auditor Irban Wil. II & 2 \\
\hline Auditor Irban Wil. III & 1 \\
\hline Auditor Irban Wil. IV & 2 \\
\hline Staf Irban Wil. I & 2 \\
\hline Staf Irban Wil. II & 4 \\
\hline Staf Irban Wil. III & 4 \\
\hline Staf Irban Wil. IV & 4 \\
\hline TOTAL & $\mathbf{2 6}$ \\
\hline
\end{tabular}

Sumber: Inspektorat Kabupaten Konawe

Pada penelitian ini digunakan adalah penelitian deskriptif dengan pendekatan survey kunatitatif. Dalam penelitian ini, data kualitatifnya adalah data yang diperoleh dari Inspektorat Daerah Kabipaten Konawe dalam bentuk informasi bukan dalam angka-angka, seperti sejarah berdiri, struktur organisasi, serta tugas pokok dan fungsi. Sedangkan data kuantitatif yang diperoleh yaitu data yang berupa bentuk hasil skor jawaban responden menggunakan pernyataan kuesioner yang diukur menggunakan Skala Likert. Analisis statistik deskriptif persentase memberikan gambaran mengenai variabel-variabel penelitian (Sistem Teknologi Informasi dan Kualitas Laporan Keuangan). Adapun skala yang 
digunakan untuk menilai pernyataan adalah skala likert dengan ukuran skor 1 sampai 5 . Untuk menentukan pengaruh antara variabel independen (Sistem Teknologi Informasi) terhadap variabel dependen yaitu Kualitas Laporan Keuangan, maka analisis statistik yang digunakan adalah Persamaan Regresi Linear Sederhana.

\section{HASIL DAN PEMBAHASAN}

\section{Tingkat Pengembalian Kuesioner}

Data pada penelitian ini diperoleh dari proses pengumpulan jawaban kuesioner yang disebar kepada 26 responden penelitian yang merupakan Tim Penyusun Laporan Keuangan Anggaran Pendapatan dan Belanja Negara (APBN) pada Balai Latihan Kerja Kendari yang dikategorikan memenuhi kriteria dalam pengukuran penggunaan Sistem Teknologi Informasi dan Kualitas Laporan Keuangan. Pelaksanaan penelitian dimulai dari penyebaran kuesioner penelitian yang ditujukan kepada seluruh responden penelitian yang terdapat di Balai Latihan Kerja Kendari. Adapun tingkat pengembalian kuesioner dapat dilihat pada tabel berikut.

Tabel 4.1

\section{Tingkat Pengembalian Kuesioner Penelitian}

\begin{tabular}{|l|l|l|}
\hline \multicolumn{1}{|c|}{ Keterangan } & Jumlah & Persentase (\%) \\
\hline Jumlah kuesioner yang disebar & 30 & $100 \%$ \\
\hline Jumlah kuesioner yang tidak kembali & 7 & $23 \%$ \\
\hline Jumlah kuesioner yang kembali & 23 & $77 \%$ \\
\hline Jumlah kuesioner yang tidak dapat diolah & 0 & $0 \%$ \\
\hline Jumlah kuesioner yang dapat diolah & 23 & $77 \%$ \\
\hline
\end{tabular}

Sumber : Data Primer diolah tahun 2020

Berdasarkan pelaksanaan penyebaran kuesioner, diperoleh jumlah kuesioner yang kembali adalah sebanyak 23 kuesioner dengan item pertanyaan dalam kuesioner telah terjawab secara keseluruhan oleh responden. Hal ini berarti bahwa seluruh kuesioner yang dibagikan kepada seluruh responden telah terjawab dan diserahkan kembali kepada peneliti. Berdasarkan hal tersebut, maka jawaban kuesioner yang kembali tersebut dapat dikategorikan layak untuk diolah lebih lanjut dalam rangka melaksanakan penelitian terkait pengaruh Locus of Control terhadap Kinerja Auditor pada Inspektorat Daerah Kabupaten Konawe.

\section{Karakteristik Responden}

Karakteristik responden yang dimaksud dalam penelitian ini adalah meliputi usia, jenis kelamin, tingkat pendidikan, dan lama bekerja di Inspektrat Daerah Kabupaten Konawe. Data Penelitian dikumpulkan dengan menyebarkan Kuisioner secara langsung untuk tim pemeriksa di Inspektorat Daerah Kabupaten Konawe. Data kuisioner yang diperoleh sebanyak 23 Kuisioner dari jumlah keseluruhan tim pemeriksa yang ada di Inspektorat Daerah Kabupaten Konawe yang disebarkan.

Tabel 4.1 Karakteristik Responden

\begin{tabular}{|c|c|c|c|}
\hline \multirow{2}{*}{ No } & \multirow{2}{*}{ Usia } & \multicolumn{2}{|c|}{ Frekuensi } \\
\hline & & Orang & Persentase \\
\hline 1 & 20-30 Tahun & 2 & $16 \%$ \\
\hline 2 & 31-40 Tahun & 12 & $48 \%$ \\
\hline 3 & $>40$ Tahun & 9 & $36 \%$ \\
\hline \multicolumn{2}{|c|}{ Jumlah } & 23 & $100 \%$ \\
\hline
\end{tabular}


Jurnal Akuntansi dan Keuangan (JAK)

Volume 6, No. 1 Februari Tahun 2021

Page: $203-216$

http://ojs.uho.ac.id/index.php/iak-uho/issue/archive

e-ISSN: 2088-4656

\begin{tabular}{|c|c|c|c|}
\hline \multirow{2}{*}{ No } & \multirow{2}{*}{ Jenis Kelamin } & \multicolumn{2}{|c|}{ Frekuensi } \\
\hline & & Orang & Persentase \\
\hline 1 & Laki-laki & 16 & $72 \%$ \\
\hline 2 & Perempuan & 7 & $28 \%$ \\
\hline \multicolumn{2}{|c|}{ Jumlah } & 23 & $100 \%$ \\
\hline
\end{tabular}

\begin{tabular}{|l|l|l|l|}
\hline \multirow{2}{*}{ No } & \multirow{2}{*}{ Lama Bekerja di Inspektorat } & Frekuensi \\
\cline { 3 - 4 } & & Orang & Persentase \\
\hline 1 & $1-10$ Tahun & 9 & $44 \%$ \\
\hline 2 & $11-20$ Tahun & 6 & $24 \%$ \\
\hline 3 & $>20$ Tahun & 8 & $32 \%$ \\
\hline Jumlah & 23 & $100 \%$ \\
\hline
\end{tabular}

\begin{tabular}{|c|c|c|c|}
\hline \multirow{2}{*}{ No } & \multirow{2}{*}{ Tingkat Pendidikan } & \multicolumn{2}{|c|}{ Frekuensi } \\
\hline & & Orang & Persentase \\
\hline 1 & SLTA & 1 & $4 \%$ \\
\hline 2 & D3 & 1 & $4 \%$ \\
\hline 3 & S1 & 14 & $54 \%$ \\
\hline 4 & S2 & 7 & $28 \%$ \\
\hline \multicolumn{2}{|c|}{ Jumlah } & 23 & $100 \%$ \\
\hline
\end{tabular}

Sumber: Data Primer diolah tahun 2020

Berdasarkan Tabel 4.1 diatas diketahui bahwa auditor pemerintah yang menjadi responden dalam penelitian ini berusia antara 20-30 tahun merupakan responden tersedikit yaitu sebanyak 4 orang (16\%) selanjutnya responden yang berusia 31-40 Tahun berjumlah 12 orang (48\%) dan responden yang berusia $>40$ tahun sebanyak 9 orang (36\%). Respnden yang berjenis kelamin Laki-laki berjumlah 18 (72\%) dan yang berjenis kelamin perempuan berjumlah 7 orang (28\%). Berdasarkan lama responden bekerja di Inspektorat Daerah Kabupaten Konawe, yaitu 1-10 Tahun berjumlah 11 orang (44\%), yang bekerja selama 1120 tahun sebanyak 6 orang (24\%), dan $>20$ tahun sebanyak 8 orang (32\%). Sedangkan untuk tingkat pendidikan, responden yang tingkat pendidikannya S2 brtjumlaah 7 orang (28\%), S1 berjumlah 14 orang (56\%), D3 berjumlah 1 orang (4\%) dan SLTA berjumlah 3 orang $(12 \%)$.

\section{Deskripsi Variabel Penelitian}

\section{a. Locus of Control (X)}

Variabel Locus of Control dimaksudkan untuk melihat Tingkat Pengendalian Diri Auditor yang ada di Inspektorat Daerah Kabupaten Konawe dalam menjalankan tugas dan tanggungjawab yang diberikan. Variabel Locus of Control dibentuk dari 2 Indikator yaitu : Locus of Control Internal dan Locus of Control External. Kedua indikator tersebut terdiri atas 13 item pernyataan. Adapun distribusi jawaban untuk variabel locus of control dan presentase kecenderungan skor jawaban adalah sebagai berikut: 
Tabel 4.3.

Distribusi Jawaban Responden atas Variabel Locus of Control (X1)

\begin{tabular}{|c|c|c|c|c|c|c|c|c|c|c|c|c|}
\hline \multirow{3}{*}{ Item } & \multicolumn{10}{|c|}{ Frekuensi Jawaban Responden } & \multirow{2}{*}{$\begin{array}{l}\text { Rata- } \\
\text { rata } \\
\text { skor }\end{array}$} & \multirow[b]{2}{*}{ Kategori } \\
\hline & $\begin{array}{l}\text { SS } \\
\text { (5) }\end{array}$ & & $\begin{array}{c}S \\
(4)\end{array}$ & & $\begin{array}{c}\mathbf{N} \\
(3)\end{array}$ & & $\begin{array}{l}\text { TS } \\
(2)\end{array}$ & & $\begin{array}{c}\text { STS } \\
\text { (1) }\end{array}$ & & & \\
\hline & $\mathbf{F}$ & $\%$ & $\mathbf{F}$ & $\%$ & $\mathbf{F}$ & $\%$ & $\mathbf{F}$ & $\%$ & $\mathbf{F}$ & $\%$ & & \\
\hline $\mathrm{X} 1.1 .1$ & 5 & $21 \%$ & 17 & $73 \%$ & 1 & $4 \%$ & 0 & $0 \%$ & 0 & $0 \%$ & $4,17 \%$ & Sangat Baik \\
\hline $\mathrm{X} 1.1 .2$ & 4 & $17 \%$ & 11 & $40 \%$ & 3 & $13 \%$ & 5 & $21 \%$ & 0 & $0 \%$ & $3,61 \%$ & Baik \\
\hline X1.1.3 & 5 & $21 \%$ & 10 & $43 \%$ & 6 & $26 \%$ & 1 & $4 \%$ & 1 & $4 \%$ & $3,74 \%$ & Baik \\
\hline X1.1.4 & 4 & $17 \%$ & 9 & $39 \%$ & 9 & $39 \%$ & 1 & $4 \%$ & 0 & $0 \%$ & $3,70 \%$ & Baik \\
\hline $\mathrm{X} 1.1 .5$ & 2 & $8 \%$ & 14 & $61 \%$ & 7 & $31 \%$ & 0 & $\%$ & 0 & $0 \%$ & $3,78 \%$ & Baik \\
\hline X1.1.6 & 2 & $8 \%$ & 14 & $61 \%$ & 4 & $17 \%$ & 3 & $13 \%$ & 0 & $0 \%$ & $3,65 \%$ & Baik \\
\hline X1.1.7 & 8 & $35 \%$ & 14 & $60 \%$ & 1 & $5 \%$ & 0 & $0 \%$ & 0 & $0 \%$ & $4,30 \%$ & Sangat Baik \\
\hline \multicolumn{11}{|c|}{ Rata-rata Indikator Locus of Control Internal } & $3,25 \%$ & Baik \\
\hline $\mathrm{X} 1.2 .1$ & 3 & $13 \%$ & 1 & $4 \%$ & 4 & $17 \%$ & 11 & $47 \%$ & 4 & $17 \%$ & $2,48 \%$ & Rendah \\
\hline $\mathrm{X} 1.2 .2$ & 4 & $17 \%$ & 6 & $26 \%$ & 8 & $34 \%$ & 5 & $21 \%$ & 0 & $0 \%$ & $3,39 \%$ & Baik \\
\hline $\mathrm{X} 1.2 .3$ & 0 & $0 \%$ & 16 & $70 \%$ & 3 & $13 \%$ & 4 & $17 \%$ & 0 & $0 \%$ & $3,52 \%$ & Baik \\
\hline $\mathrm{X} 1.2 .4$ & 0 & $0 \%$ & 8 & $34 \%$ & 7 & $30 \%$ & 6 & $26 \%$ & 2 & $8 \%$ & $2,91 \%$ & Cukup \\
\hline $\mathrm{X} 1.2 .5$ & 5 & $23 \%$ & 11 & $47 \%$ & 7 & $30 \%$ & 0 & $0 \%$ & 0 & $0 \%$ & $3,91 \%$ & Baik \\
\hline $\mathrm{X} 1.2 .6$ & 2 & $8 \%$ & 1 & $4 \%$ & 7 & $30 \%$ & 10 & $43 \%$ & 3 & $13 \%$ & $2,52 \%$ & Rendah \\
\hline \multicolumn{11}{|c|}{ Rata-rata Indikator Locus of Control External } & $3,12 \%$ & Cukup \\
\hline \multicolumn{11}{|c|}{ Rata-rata Variabel Locus of Control } & $3,18 \%$ & Cukup \\
\hline
\end{tabular}

Sumber: Data Primer diolah tahun 2020

Tabel 4.3 menunjukkan pernyataan responden atas variabel Locus of Control (X1), menurut tanggapan responden adalah Cukup dengan rata-rata jawaban sebesar 3,18\%. Dari persepsi responden tampak bahwa inndikator Locus of Control Internal (X1.1), memiliki jawaban responden yang lebih tinggi dibandingkan dengan indikator lainnya yaitu Locus of Control Eksternal.

Indikator Locus of Control Internal (X1.1) menurut tanggapan responden termasuk dalam kategori Baik/Tinggi dengan nilai persentase 3,25\%. Hal ini menunjukkan bahwa locus of control internal merupakan indikator yang penting bagi pegawai Inspektorat Kabupaten Konawe untuk meningkatkan Kinerjanya. Dengan memiliki Locus of Control Internal, Pegawai Inspektorat Kabupaten Konawe dapat mengendalikan dirinya untuk tidak terlibat dalam perilaku-perilaku yang menyimpang.

Indikator Locus Of Control Eksternal (X1.2) menurut tanggapan responden termasuk dalam kategori Cukup/Sedang dengan nilai persentase rata-rata yaitu 3,12\%. Hal ini berarti Pegawai Inspektorat Kabupaten Konawe cukup memahami bahwa tidak semua peristiwa/kejadian di lingkungan kita terjadi karena keberuntungan.

\section{b. Kinerja (Y)}

Variabel Kinerja Auditor adalah variabel dependen dalam penelitian ini. Di dalam mempertimbangkan Kinerja Auditor, penelitian ini mengutamakan sejumlah output dari outcomes yang dihasilkan oleh suatu kelompok atau organisasi tertentu baik dalam bentuk materi (kuantitatif) maupun berbentuk nonmateri (kualitatif). Variabel ini terdiri atas 9 item pernyataan yang terbagi ke dalam 3 indikator yakni Kualitas, Kuantitas dan Ketepatan Waktu. Adapun distribusi jawaban untuk variabel Kinerja dan persentase kecenderungan skor jawaban adalah sebagai berikut: 
Tabel 4.4

Distribusi Jawaban Responden atas Variabel Kinerja Auditor (Y)

\begin{tabular}{|c|c|c|c|c|c|c|c|c|c|c|c|c|}
\hline \multirow{3}{*}{ Item } & \multicolumn{10}{|c|}{ Frekuensi Jawaban Responden } & \multirow{2}{*}{$\begin{array}{c}\text { Rata- } \\
\text { rata } \\
\text { skor }\end{array}$} & \multirow[b]{2}{*}{ Kategori } \\
\hline & $\begin{array}{l}\text { SS } \\
(5) \\
\end{array}$ & & $\begin{array}{c}S \\
(4) \\
\end{array}$ & & $\begin{array}{c}\mathbf{N} \\
(3) \\
\end{array}$ & & $\begin{array}{l}\text { TS } \\
\text { (2) }\end{array}$ & & $\begin{array}{c}\text { STS } \\
\text { (1) }\end{array}$ & & & \\
\hline & $\mathbf{F}$ & $\%$ & $\mathbf{F}$ & $\%$ & $\mathbf{F}$ & $\%$ & $\mathbf{F}$ & $\%$ & $\mathbf{F}$ & $\%$ & & \\
\hline Y1.1.1 & 1 & $4 \%$ & 20 & $87 \%$ & 2 & $9 \%$ & 0 & $0 \%$ & 0 & $0 \%$ & $3,96 \%$ & Baik \\
\hline Y1.1.2 & 4 & $17 \%$ & 16 & $70 \%$ & 3 & $13 \%$ & 0 & $0 \%$ & 0 & $0 \%$ & $4,04 \%$ & Baik \\
\hline Y1.1.3 & 5 & $22 \%$ & 9 & $39 \%$ & 6 & $26 \%$ & 3 & $13 \%$ & 0 & $0 \%$ & $3,70 \%$ & Baik \\
\hline \multicolumn{11}{|c|}{ Rata-rata Indikator Kualitas } & $3,90 \%$ & Baik \\
\hline Y1.2.1 & 4 & $17 \%$ & 2 & $9 \%$ & 17 & $74 \%$ & 0 & $0 \%$ & 0 & $0 \%$ & $3,43 \%$ & Baik \\
\hline Y1.2.2 & 2 & $9 \%$ & 15 & $65 \%$ & 3 & $13 \%$ & 3 & $13 \%$ & 0 & $0 \%$ & $3,70 \%$ & Baik \\
\hline Y1.2.3 & 4 & $17 \%$ & 17 & $74 \%$ & 2 & $9 \%$ & 0 & $0 \%$ & 0 & $0 \%$ & $4,09 \%$ & Baik \\
\hline \multicolumn{11}{|c|}{ Rata-rata Indikator Kuantitas } & $3,74 \%$ & Baik \\
\hline Y1.2.1 & 4 & $17 \%$ & 7 & $31 \%$ & 12 & $52 \%$ & 0 & $0 \%$ & 0 & $0 \%$ & $3,65 \%$ & Baik \\
\hline Y1.2.2 & 1 & $4 \%$ & 17 & $74 \%$ & 5 & $22 \%$ & 0 & $0 \%$ & 0 & $0 \%$ & $3,83 \%$ & Baik \\
\hline Y1.2.3 & 5 & $22 \%$ & 15 & $65 \%$ & 3 & $13 \%$ & 0 & $0 \%$ & 0 & $0 \%$ & $4,09 \%$ & Baik \\
\hline \multicolumn{11}{|c|}{ Rata-rata Indikator Ketepatan Waktu } & $3,85 \%$ & Baik \\
\hline \multicolumn{11}{|c|}{ Rata-rata Variabel Locus of Control } & $\mathbf{3 , 8 7}$ & Baik \\
\hline
\end{tabular}

Sumber: Data Primer diolah tahun 2020

Tabel 4.4 menunjukkan pernyataan responden bahwa variabel Kinerja Auditor (Y1) menurut tanggapan responden adalah Baik dengan nilai persentase rata-rata sebesar 3,87\%. Dari persepsi responden tampak bahwa indikator Kualitas (Y1.1) memiliki rata-rata jawaban responden yang lebih tinggi dibandingkan dengan indikator kuantitas (Y1.2) yaitu 3,74\% dan juga indikator ketepatan waktu (Y1.3) yaitu sebesar 3,85\%.

Indikator Kualitas (Y1.1) menurut tanggapan responden termasuk dalam kategori baik dengan nilai persentase rata-rata 3,90\%. Hal ini berarti bahwa Pegawai Inspektorat Daerah Kabupaten Konawe telah melaksanakan amanahnya dengan kualitas yang memadai.

Indikator Kuantitas (Y1.2) menurut tanggapan responden termasuk dalam kategori baik dengan nilai persentase rata-rata sebesar 3,74\% yang artinya Pegawai Inspektorat Daerah Kabupaten Konawe telah melaksanakan tugasnya dengan produktif.

Indikator Ketepatan Waktu (Y1.3) menurut tanggapan responden termasuk dalam kategori Baik dengan nilai persentase sebesar 3,85\% yang artinya Pegawai Inspektorat Daerah Kabupaten Konawe telah melaksanakan kewajibannya dengan efektif dan efisien.

\section{Hasil Pengujian Hipotesis}

Adapun hasil pengujian hipotesis untuk melihat pengaruh Locus of Control terhadap Kinerja Auditor pada Inspektorat Daerah Kabupaten Konawe, maka dilakukan dengan menggunakan analisis sebagai berikut.

\section{Analisis regresi linear sederhana}

Analisis regresi sederhana digunakan untuk meramalkan bagaimana keadaan (naik turunnya) variabel dependen (kriterium), bila ada satu variabel independen sebagai prediktor dimanipulasi dengan cara menaik turunkan nilainya, dimana dalam penelitian ini dilakukan untuk membuktikan pengaruh locus of control terhadap kinerja auditor pada Inspektorat Daerah Kabupaten Konawe. Dengan menggunakan data hasil penelitian, seperti yang digambarkan pada uraian deskripsi variabel, maka digunakan metode regresi sederhana yang diolah dengan menggunakan Program SPSS, dari hasil pengolahan diperoleh nilai sebagaimana yang tercantum dalam tabel sebagai berikut: 
Jurnal Akuntansi dan Keuangan (JAK)

Volume 6, No. 1 Februari Tahun 2021

Page: $203-216$

http://ojs.uho.ac.id/index.php/jak-uho/issue/archive

e-ISSN: 2088-4656

Tabel 4.9

\begin{tabular}{|c|c|c|c|c|c|c|c|c|}
\hline \multirow{2}{*}{ Model } & \multicolumn{2}{|c|}{$\begin{array}{c}\text { Unstandardized } \\
\text { Coefficients }\end{array}$} & $\begin{array}{l}\text { Standardized } \\
\text { Coefficients }\end{array}$ & \multirow{2}{*}{$\mathrm{T}$} & \multirow{2}{*}{ Sig. } & \multicolumn{3}{|c|}{ Correlations } \\
\hline & B & Std. Error & Beta & & & $\begin{array}{l}\text { Zero- } \\
\text { order }\end{array}$ & Partial & Part \\
\hline Constant & 1,217 & ,337 & & 3,60 & ,002 & & & \\
\hline $\begin{array}{l}1 \text { Locus of Control } \\
\text { X1 }\end{array}$ & 0,743 & ,094 & ,86 & 7,89 &, 000 &, 865 &, 865 & 5,865 \\
\hline $\mathrm{R}^{2}$ & 0,748 & & & & & & & \\
\hline t table & 1,721 & & & & & & & \\
\hline D-W & 1,758 & & & & & & & \\
\hline
\end{tabular}

Sumber : Data Primer Diolah Tahun 2020

Berdasarkan ringkasan hasil analisis regresi linear sederhana pada Tabel 4.9 diperoleh persamaan regresi linear sederhana sebagai berikut :

$$
Y=0,217+0,743 X+\varepsilon
$$

Berdasarkan Estimasi Regresi Linear Sederhana diatas dapat diuraikan sebagai berikut : Koefisien regresi untuk variabel locus of control adalah 0,743 kali, dapat diartikan bahwa terdapat hubungan yang positif antara locus of control terhadap kinerja auditor. Sehingga dapat diartikan bahwa apabila variabel locus of control terjadi kenaikan 1 kali, maka variabel terikat kinerja auditor akan mengalami kenaikan sebesar 0,743 kali.

\section{Analisis regresi linear sederhana}

Analisis regresi linear sederhana hanya melakukan penilaian pengaruh antara satu variabel bebas dengan satu variabel terikat, sehingga dalam metode analisis statistiknya tidak menggunakan uji simultan (uji F). Analisis regresi linear sederhana digunakan untuk mengetahui pengaruh masing-masing variabel bebas terhadap variabel terikat, yaitu variabel Sistem Teknologi Informasi terhadap Kualitas Laporan Keuangan (Y). Berdasarkan hasil analisis statistik, diperoleh nilai $\mathrm{t}_{\text {hitung }}$ untuk variabel Sistem Teknologi Informasi (X) adalah 7,850 dan nilai $t_{\text {tabel }} 1,721$

Berdasarkan hasil perbandingan antara $t_{\text {hitung }}$ dan $t_{\text {tabel }}$ diketahui nilai $t_{\text {hitung }}$ $(7,850)>t_{\text {tabel }}(1,721)$ dan juga dapat dilihat bahwa tingkat signifikansi $(0,000)<$ dari $\alpha$ $(0,05)$. Berdasarkan nilai tersebut, maka dapat disimpulkan bahwa $\mathrm{H}_{0}$ ditolak atau $\mathrm{H}_{1}$ diterima yang berarti bahwa Locus of Control berpengaruh signifikan terhadap Kinerja Auditor pada Inspektorat Daerah Kabupaten Konawe.

\section{Koefisien Determinasi $\left(\mathbf{R}^{2}\right)$}

Untuk mengetahui besarnya kontribusi pengaruh Locus of control berpengaruh terhadap kualitas Kinerja Auditor pada Inspektorat Daerah Kabupaten Konawe, maka dilakukan dengan melihat koefisien determinasinya $\left(\mathrm{R}^{2}\right)$. Berdasarkan Tabel 4.9 diketahui nilai R-Square atau $\mathrm{R}^{2}=0,748$. Hal ini berarti bahwa kontribusi variabel bebas Locus of Control terhadap kinerja auditor pada Inspektorat Daerah Kabupaten Konawe adalah sebesar 0,748 atau $74,8 \%$, sedangkan sisanya yaitu $26,2 \%$ merupakan pengaruh dari variabel lain yang tidak masuk dalam penelitian ini, misalnya variabel Gaya Kepemimpinan, Budaya Organisasi, Komitmen Kerja, dan lain sebagainya yang relevan dengan arah penelitian. 


\section{Pembahasan}

\section{Pengaruh Penggunaan Locus of Control Terhadap Kinerja Auditor Pada Inspektorat Daerah Kabupaten Konawe}

Permasalahan inti yang ingin dijawab dalam penelitian ini adalah "Apakah Locus of Control berpengaruh Signifikan terhadapa Kinerja Auditor Pada Inspektorat Daerah Kabupaten Konawe?"

Secara empiris, hasil penelitian ini menginformasikan bahwa Locus of Control yang dicerminkan oleh dimensi (1) Locus of Control Internal (2) Locus of Control Eksternal, berpengaruh secara signifikan terhadap Kinerja Auditor. Besarnya pengaruh Locus of control dalam mendorong kinerja auditor di Inspektorat Daerah Kabupaten Konawe adalah sebesar $74,8 \%$ dan sisanya sebesar $26,2 \%$ merupakan variabel-variabel lain yang tidak diteliti dalam penelitian ini.

Dari hasil uji signifikansi diperoleh $t$-hitung sebesar 7,890 > dari t-tabel yaitu sebesar 1,721 atau dengan tingkat signifikan $t$ sebesar $0,000<$ pada $\alpha=0,05$, Sehingga dapat disimpulkan bahwa locus of control memiliki dampak yang signifikan bagi kinerja auditor.

Hasil penelitian ini mengindikasikan bahwa semakin tinggi Pengendalian diri seorang Auditor, maka akan semakin tinggi pula kinerja auditor itu sendiri. Hal ini dijelaskan oleh tabel regresi diatas dimana Koefisien regresi untuk variabel Pengawasan Melekat adalah 1,039 kali, dapat diartikan bahwa apabila variabel Pengawasan Melekat terjadi kenaikan 1 kali, maka variabe1 terikat kinerja pegawai akan mengalami kenaikan sebesar 1,039 kali.

Hal tersebut menunjukkan bahwa locus of control memiliki nilai yang berarti bagi kinerja pegawai di Inspektorat Daerah Kabupaten Konawe. Hal ini dikarenakan setiap pimpinan harus turut serta mendukung kinerja Auditor mengingat para pegawai negeri sipil yang bekerja Inspektorat Daerah Kabupaten Konawe memiliki usia diatas 40 tahun yang tinggi yakni $36 \%$. Sehingga proses kerja sangat didominasi oleh pengawasan yang dilakukan oleh setiap pimpinan. Sehingga dalam penelitian ini kontribusi locus of control dalam menjelaskan kinerja auditor sangat tinggi yakni $74,8 \%$ hal ini sejalan dengan penelitian yang dilakukan oleh Emiral Mahdy (2012) yang menerangkan bahwa kontribusi locus of control dan kompleksitas tugas terhadap kinereja sebesar 93,2\%.

Hal ini juga diperkuat oleh pendapat Luthans (2006)) yang menyatakan bahwa karyawan yang memiliki kontrol internal merasa bahwa secara personal mereka dapat mempengaruhi hasil kinerja melalui kemampuan, keahlian atau usaha mereka sendiri. Karyawan yang memiliki kontrol eksternal merasa bahwa kekuatan eksternal seperti keberuntungan dan kesulitan tugas mengontrol hasil kinerja mereka.

Berdasarkan temuan empiris yang menunjukkan adanya pengaruh yang tidak hanya signifikan melainkan juga berpengaruh positif antar locus of control dengan kinerja auditor, hasil penelitian ini memberikan beberapa informasi berikut. Pertamalocus of cntrol memberikan pengaruh yang berarti terhadap kinerja pegawai. Kedua, salah satu cara meningkatkan kinerja pegawai adalah dengan meningkatkan kendali diri. Ketiga, temuan ini memberikan penegasan terhadap teori-teori yang menyebutkan bahwa kinerja auditor dipengaruhi oleh locus of control.

Hasil penelitian ini mendukung penelitian yang dilakukan oleh Emiral Mahdy (2012) dimana hasil penelitiannya menyebutkan bahwa locus of control berpengaruh signifikan positif terhadap kinerja auditor. Hasil penelitian ini menggambarkan bahwa auditor yang memiliki kontrol internal cenderung memiliki kinerja audit yang lebih tinggi dibandingkan auditor yang memiliki kontrol eksternal.

Hasil penelitian ini juga mendukung penelitian yang dilakukan oleh Intan Maulida Zuhra (2010) dimana hasil penelitiannya menyebutkan bahwa locus of control berpengaruh 
terhadap penerimaan penyimpangan perilaku audit. Hasil penelitian ini menunjukkan bahwa ketika auditor memiliki kontrol internal yang rendah maka akan berpotensi untuk melakukan penyimpangan-penyimpangan atau tindakan yang merugikan banyak pihak terutama masyarakat. Sebagai orang yang telah diberikanah untuk melakukan pemeriksaan tentu saja auditor harus menjunjung tinggi etika profesinya agar kepercayaan masyarakat tidak hilang.

Apabila dilihat dari fenomena penelitian yang terlihat pada Inspektorat Daerah Kabupaten Konawe yakni masih adanya temuan yang fantastis tersebut (sejumlah desa fiktif di Konawe) disebabkan karena auditor tidak memiliki kendali internal yang tinggi, hal tersebut kemudian berdampak pada Kabupaten Konawe menjadi isu nasional dan dibahas di berbagai media baik cetak maupun elektronik.

Berdasarkan fenomena yang disebutkan di atas tersebut, tidak dapat dipungkiri bahwa dalam pelaksanaan suatu pekerjaan pasti akan selalu ditemukan adanya suatu kendala atau masalah. Meskipun besar atau kecil, namun kendala tersebut dapat dihindari ketika auditor memiliki kendali internal yang tinggi. Seorang Auditor yang independen akan senantiasa menjunjung tinggi moral dan etika profesinya.

Namun secara garis besar, hasil analisis jawaban responden diketahui bahwa indikator Locus of Control Internal menunjukkan angka yang cukup tinggi. Hal ini menunjukkan bahwa Pegawai Inspektorat telah memiliki Pengendalian Diri Internal (Locus of Control Internal) yang Cukup Baik untuk memastikan bahwa tindakan-tindakan yang merugikan dapat dihindari. Sedangkan Pada indikator Locus of Control Eksternal menunjukkan bahwa Pegawai Inspektorat Daerah Kabupaten Konawe sudah mengurangi Persepsi bahwa setiap peristiwa terjadi karena adanya keberuntungan dan tidak mengedepankan nepotisme, terbukti dari hasil analisis jawaban responden yang menunjukkan angka yang rendah.

Dengan demikian dapat dijelaskan bahwa locus of control mempengaruhi kinerja auditor Inspektorat Daerah Kabupaten Konawe.

\section{Kesimpulan}

\section{KESIMPULAN DAN SARAN}

Berdasarkan hasil penelitian dan pembahasan, maka dapat diambil kesimpulan bahwa locus of control berpengaruh signifikan terhadap kinerja auditor di Inspektorat Daerah Kabupaten Konawe yang artinya bahwa apabila Pengendalian diri seorang auditor itu tinggi maka kinerja auditor juga akan meningkat

Selain itu locus of control juga memiliki kontribusi yang positif terhadap kinerja pegawai dimana jika pengendalian diri ditingkatkan maka akan berdampak baik terhadap kinerja auditor.

\section{Saran}

Berdasarkan kesimpulan yang dikemukakan sebelumnya, maka peneliti dapat memberikan saran-saran sebagai berikut.

1. Inspektur Inspektorat Daerah Kabupaten Konawe harus lebih maksimal lagi dalam memantau kinerja karyawannya, hal ini dilakukan untuk mendapatkan hasil yang maksimal. Selain itu, pimpinan Inspektorat juga harus terus meningkatkan Karyawannya agar melakkukan pengendalian diri agar terhindar dari praktik-praktik yang tentu saja akan merugikan negara.

2. Peneliti menyadari bahwa penelitian ini masih jauh dari kata sempurna, dan penelitian ini hanya berfokus pada satu variabel saja, sehingga diharapkan peneliti selanjutnya untuk menguji variabel lain yang mungkin berpengaruh terhadap kineja karyawan yang tidak diukur dalam penelitian ini. 


\section{DAFTAR PUSTAKA}

Ayudiati. 2010. Analisis Pengaruh Locus of Control Terhadap Kinerja dengan Etika Islam sebagai Variabel Moderating (Studi Pada Karyawan Tetap Bank Jateng Semarang). Skripsi. Universitas Diponegoro, Semarang.

Bastian, Indra, 2001. Akuntansi Sektor Publik. BPFE, Universitas Gajah Mada. Yogyakarta.

Budiman, Perwira S. 2016. "Pengaruh Striktur Audit, Locus Of Control dan Komitmen Organisasi Terhadap Kinerja Auditor Pemerintah (Studi Empiris pada Auditor Pemerintah di Inspektorat Kab. Agam, Kota Padang, dan Kota Padang Panjang. Skripsi Online. Padang: Fakultas Ekonomi, Universitas Negeri Padang.

Desapedia.id. Wawancara Eksklusif: Aktivis Anti Korupsi Beberkan Soal Desa Fiktif di Konawe. 9 Nopember 2019.

Engko, Cecilia dan Gundono. "Pengaruh Kompleksitas Tugas dan Locus of Control terhadap hubungan antara gaya kepemimpinan dan kepuasan kerja auditor". Simposium Nasional Akuntansi X, AMKP-08, Makassar, 2007.

Fred Luthans. 2006. Perilaku Organisasi. Edisi Sepuluh. Yogyakarta: PT Andi.

Mahdy, Emiral. 2012. Analisis pengaruh locus of control dan Kompleksitas Tugas Audit Terhadap Kinerja Auditor Internal (Studi Pada Auditor Internal Pemerintah yang bekerja pada Inspektorat Provinsi Jawa Tengah). Skripsi Online. Semarang: Fakultas Ekonomi dan Bisnis, Universitas Diponegoro.

Mulyadi. 2002. Auditing, Edisi Kelima, Cetakan Pertama. Jakarta. : Salemba Empat.

Robbins, Stephen P. 2001. Perilaku Organisasi, Edisi Kedelapan, PT Prenhallindo, Jakarta. Standar Profesi Audit Internal (SPAI). 2004. Jakarta: Salemba Empat.

Wirawan., 2009. Evaluasi Kinerja Sumber Daya Manusia Teori Aplikasi dan Penelitian. Jakarta: Salemba Empat.

Wikipedia.org.

Yuesti, Anik. 2017. Akuntansi Keperilakuan. Yogyakarta : AB Publisher..

Zuhra, Intan M. 2010. "Locus of Control, Time Budget Pressure dan Penyimpangan Perilaku dalam Audit". Jurnal Telaah dan Riset Akuntansi, Vol 2. 